University of South Carolina

Scholar Commons

7-1992

\title{
A Descriptive Analysis and Academic Genealogy of Major Contributors to JTPE in the 1980s
}

Murrary F. Mitchell

University of South Carolina - Columbia, mmitchel@mailbox.sc.edu

Follow this and additional works at: https://scholarcommons.sc.edu/pedu_facpub

Part of the Education Commons

\section{Publication Info}

Published in Journal of Teaching in Physical Education, Volume 11, Issue 4, 1992, pages 426-442. http://journals.humankinetics.com/jtpe-contents (C) 1992 by Human Kinetics Publishers, Inc.

This Article is brought to you by the Physical Education, Department of at Scholar Commons. It has been accepted for inclusion in Faculty Publications by an authorized administrator of Scholar Commons. For more information, please contact digres@mailbox.sc.edu. 


\title{
A Descriptive Analysis and Academic Genealogy of Major Contributors to JTPE in the 1980s
}

\author{
Murray F. Mitchell \\ Rutgers University
}

\begin{abstract}
Information about whose knowledge is accepted as important is valuable in understanding how a profession evolves. The term elders describes the individuals who control invisible networks of prestige and who determine what information is accepted for publication in professional journals. These published works stand as the foundation for the knowledge base of a discipline. The purpose of this article was to identify the elders in physical education teacher education (PETE) and to trace their academic genealogy. Elders were defined as major contributors to the Journal of Teaching in Physical Education from 1981 through 1989. The articles published by these subjects were generally, but not exclusively, research-related. Hence, aspects related to faculty research performance were selected as descriptors that may facilitate comparisons of PETE professors to other groups of professors and to future PETE professors. Subjects' gender, prestige of doctoral program, mentoring, and prestige of current institution of employment were studied as these indicators represent major correlates with research productivity.
\end{abstract}

In an analysis of higher education, Clark (1987) described university professors as existing in "small and different" worlds with their "invisible networks." Sykes (1988) described disciplines in higher education slightly differently. Employing the imagery of "'academic villages," Sykes portrayed disciplines as "complete with elders, wise men, and elaborate rituals of initiation and ostracism" (p. 12). The value of these metaphorical models can be found in the extent that they enlighten the understanding of struggles for prestige and power and resultant implications for the development of an accepted knowledge base for a discipline. In other words, information about whose knowledge is accepted as important is valuable in understanding how a profession evolves and for having any hope of exerting control over that evolution.

Elders may be a useful term in the study of the development of a profession as these are the individuals described by Sykes (1988) as being in control of "the informal hierarchy of status, reputation, and prestige', (p. 12). Furthermore, through these control mechanisms, or invisible networks, elders determine, to a large extent, what information is accepted for publication in professional journals.

Murray F. Mitchell is with the Department of Exercise Science and Sport Studies at Rutgers University, New Brunswick, NJ 08903-0270. 
These published works stand as the foundation for the knowledge base of a discipline. The purpose of this article is to identify the elders in physical education teacher education (PETE) and to trace their academic genealogy.

Unfortunately, little is known about teacher educators in general (Lanier \& Little, 1986) or about PETE professors (Williamson, 1990a). The need for better understanding PETE professors has been identified by Locke (1984), Dodds (1989), and Lawson (1991), among others.

There are several problems plaguing the study of teacher educators. From a definitional standpoint, there is no shared understanding as to who teacher educators are or what they do. Lanier and Little (1986) suggested that "while it is known that a teacher educator is one who teaches teachers, the composite of those who teach teachers is loosely defined and constantly changing'" (p. 528). These authors go on to observe that "teacher education is practically everyone's, and yet no one's obvious responsibility or priority" (p. 529). The only consistent observation appears to be the inverse relationship noted between prestige and degree of involvement with the formal education of teachers (Borrowman, 1965; Judge, 1982; Lanier \& Little, 1986).

There have been attempts to create conceptual models identifying different types of teacher educators in general (cf. Carter, 1981; Massanari, Drummond, Houston, \& Edelfelt, 1978; Ryan, 1974) and physical educators in particular (cf. Mitchell, 1990a). Unfortunately, none of these models has yet captured the uniqueness of physical education faculty, and no one model has been accepted as adequately representative of all who have an interest in and make contributions to teacher education.

Information about teacher education professors (Wisniewski \& Ducharme, 1989) and about PETE professors is growing. Recent work on the latter group includes data on scholarly behaviors (Mitchell, 1990b), PETE professors' perceptions of the effectiveness of graduates from their programs (Placek \& Dodds, 1990), an ethnographic account of life as a teacher educator (Schempp \& Graber, 1990), insights into relationships between teacher-education reform and teacher educators (Scott, 1990), and descriptions of various work roles (Williamson, 1990b). There is still, however, much that remains to be studied with regard to PETE professors, and it is work with a variety of potential benefits. Lawson (1991), for example, identified seven justifications for examining PETE professors: (a) to enhance the understanding of opportunities and constraints surrounding the work of PETE professors; (b) to provide insights into how PETE professors are similar to and different from other kinds of teacher education professors and other kinds of professors; (c) to provide career counseling and faculty-development systems for professors; (d) to provide immediate and long-term indications of the impact of doctoral programs; (e) to understand and assess preservice teacher-certification programs; (f) to help PETE professors perform better as teachers, researchers, and/or change agents through interventionist work; and ( $\mathrm{g}$ ) to understand PETE professors as participants in efforts aimed at the improvement and reform of schools. A key goal of this paper is to extend the existing knowledge base on PETE professors through the examination of an important subset of this group.

\section{PETE Academic Villages and Elders}

\section{Defining Elders}

Different definitions exist for the concept of an elder in particular academic villages. The concept is abstract and involves a largely subjective attribution. 
One interpretation of academic villages and elders was presented by Lawson (1991). He used identifiable doctoral programs, linked with prestigious researchers, to locate paradigmatic communities in PETE. He provides six examples of these communities that might also be interpreted as examples of elders in the PETE academic village: (a) Daryl Siedentop and The Ohio State University program for interventionist research; (b) Ann Jewett and the University of Georgia program for curriculum research; (c) Judith Rink and the University of South Carolina program for research that links motor learning, development, and physical education pedagogy; (d) Lawrence F. Locke and the University of Massachusetts program for research on teaching, gender equity, and teacher education; (e) William G. Anderson and the Columbia University program for research on teaching and teacher development; and, though not linked to a particular program or person, (f) the emergent paradigmatic community for occupational socialization research, with members trained in several different universities. These examples stand as one way of defining elders and provide initial insight into the identity of current elders in the PETE academic village as well as where to expect to find the genealogical roots of future elders.

For the present investigation, an alternative definition was used to define elders. This alternative definition reflects an attempt to provide an objective quantification of contributions to the discipline. Elders were defined as major contributors (author or coauthor of three or more articles from 1981 through 1989) to the Journal of Teaching in Physical Education (JTPE). This journal was deemed an appropriate indicator because of its mandate and impact. JTPE began in the spring of 1981. The mandate for the journal, as stated by the founding editors, Michael Metzler and Mark Freedman (1981), was to create "an outlet for research and topical discussion articles for the discipline of physical education teacher education" (p. 1).

The impact of JTPE has been identified indirectly through data indicating the extent to which physical educators read JTPE. Metzler and Freedman (1985) noted that approximately $18 \%$ of the physical educators in their study subscribed to this journal. Mitchell (1988) reported that $20 \%$ of the subjects in his study regularly read JTPE. In each of these studies, many journals were listed by individual subjects, with JTPE ranking among the top four most popular. These ratings are more significant than first impressions might indicate in light of what Sykes (1988) has called the "One Percent Rule." Sykes suggested that half of all technical reading is done in less than $1 \%$ of the scientific journals (p. 117). Hence, it may be hypothesized that the authors publishing in JTPE are likely to have an appreciable impact upon the subsequent knowledge, skills, attitudes, and values of teacher educators and their students (first as preservice teachers and later as practicing professionals). Consequently, an examination of the major influences over these authors is warranted. From such an examination may come insights into the past, present, and future potential of scholarly work in the profession as those publishing frequently in $J T P E$ are candidates for the mantle of elder in the PETE academic village.

\section{Describing Elders}

Selecting appropriate descriptors to provide a relevant profile of PETE elders (and aspiring elders) is problematic. Because elders have been defined by their repeated contributions to JTPE, information used to describe such scholarly behavior seems most appropriate. The articles published by subjects in this study are generally, but not exclusively, research-related articles. Hence, aspects related to faculty research 
performance were selected as descriptors that may facilitate future comparisons of PETE professors to other groups of professors and to future PETE professors.

Creswell (1985) presented a review of research that examined correlates of faculty research performance. Among the major correlates studied were the following: intelligence test scores, motivation, personality characteristics, stress, age, gender, prestige of doctoral program and mentoring, prestige of employing institution, resources and assignment, colleagues, rank and tenure, early productivity, preference for research, and disciplinary differences. No study reviewed included all possible correlates of faculty research performance. He concluded that research performance is a product of a complex set of correlates and that the complete causal model has yet to be specified (Creswell, 1985, p. 44). As a result, insight into the most appropriate correlates remains something of a mystery.

In the present study, subjects' gender, prestige of doctoral program, mentoring, and prestige of the current institution of employment were identified. These indicators represent major correlates with research productivity, and all were accessible descriptors.

\section{Data Collection and Analysis}

The names of all authors of articles in JTPE from the Introductory Issue through Volume 9, Issue 1, were tabulated. All authors or coauthors of three or more articles were identified (book reviews were not included in this analysis). There were 233 different authors contributing to JTPE in this time period; 44 of these (approximately 18.9\%) met the criterion for inclusion in the present study.

Letters were sent to the authors identified, requesting their cooperation in identifying their major advisers, year of graduation, highest degree obtained, type of degree, and focus of study. Follow-up telephone calls were used as prompts when required to obtain the requested information. Two subjects responded by telephone, and all others returned the post cards included in the original request for information, resulting in a $100 \%$ response rate.

Information on the background of each author was solicited through simple, direct questions. Responses to each question were then tabulated. The raw numbers and percentages are presented in the following section.

\section{Results and Discussion}

Of the 44 subjects identified, 17 (38.6\%) were female and 27 (61.4\%) were male. All subjects had obtained terminal degrees (PhD, EdD, or PED). The distribution of subjects by degree type and gender appears in Table 1 . The PhD appears to be slightly more common than the doctorate in education for both female and male subjects.

Lawson (1990) suggested that professional education scholars (faculty receiving a doctorate since 1970) are an emergent and increasingly powerful group in PETE academic villages. The professional education scholars referred to by Lawson might also be identified as what Sykes (1988) called elders (or aspiring elders) in the academic village. The source of power for this group lies in the perceived prestige associated with their work orientation. This orientation is geared more to basic research than to clinical competence (Lawson, 1990).

The distribution of subjects in this study by gender and year of receipt of terminal degree appears in Table 2. As might be expected, given the orientation 
Table 1

Degree Type by Gender

\begin{tabular}{clll}
\hline Degrees & Females (\%) & Males (\%) & Totals (\%) \\
\hline EdD & & & \\
$(\%)$ & $8(18.2)$ & $12(27.3)$ & $20(45.5)$ \\
PhD & $(47.1)$ & $(44.4)$ & \\
$(\%)$ & $9(20.5)$ & $14(31.8)$ & $23(52.3)$ \\
PED & $(52.9)$ & $(51.9)$ & $1(2.3)$ \\
$(\%)$ & $0(0)$ & $1(2.3)$ & $44(100)$ \\
Totals & $(0)$ & $(3.7)$ & \\
\hline
\end{tabular}

Table 2

Year of Degree

\begin{tabular}{|c|c|c|c|}
\hline Years & Females (\%) & Males (\%) & Totals \\
\hline $\begin{array}{l}\text { Prior to } 1970 \\
(\%) \\
1970-1979 \\
(\%) \\
1980-1989 \\
(\%) \\
\text { Totals }\end{array}$ & $\begin{array}{l}2(28.6) \\
(11.8) \\
3(18.8) \\
(17.6) \\
12(57.1) \\
(70.6) \\
17(38.6)\end{array}$ & $\begin{array}{l}5(71.4) \\
(18.5) \\
13(81.3) \\
(48.1) \\
9(42.9) \\
(33.3) \\
27(61.4)\end{array}$ & $\begin{array}{l}7 \\
(15.9) \\
16 \\
(36.4) \\
21 \\
(47.7) \\
44(100)\end{array}$ \\
\hline
\end{tabular}

of JTPE to disseminate research, this pool of subjects is dominated by individuals who have received their doctorates since 1970 . The substantial increase in the number of female major contributors receiving their degrees in the 1980s marks an interesting change from previous patterns (cf. Freeman, 1977; Metzler \& Freedman, 1985; Safrit, 1979). These data provide a baseline against which future studies of gender differences in the field may be measured.

Metzler and Freedman (1985) described PETE professors as a group with little in common. A sense of this diversity became evident in this study when subjects were asked to identify the focus of their doctoral programs. Many subjects identified more than one area of focus for their doctoral studies. Furthermore, a variety of descriptors were used for the same focus; hence, synonyms have been grouped where appropriate. Across the 44 subjects, 21 different foci were identified. The most common area of study involved teacher education, either generically or specifically focusing on physical education. The next most common focus involved some aspect of curriculum. The study of teachers and teacher behavior was the third most popular area of study, only slightly more popular than a general course of study in physical education. Other areas of study received minimal mention. The various descriptions are listed in Table 3. 
Table 3

Doctoral Program Focus Descriptors

$N^{*} \quad$ Descriptors

18 Physical education teacher education; teacher education; teacher education in physical education; teacher education with elementary emphasis

11 Curriculum; curriculum development; curriculum \& instruction; curriculum theory; physical education curriculum

8 Teacher behavior; teaching behavior; analysis of teaching behavior in sport setting; teaching analysis; teaching; teachers

7 Generalist; physical education

5 Pedagogy; sport pedagogy

4 Applied behavior analysis

4 Developmental psychology; educational psychology; psychological education; psychology

4 Instruction; instructional effectiveness

4 Research on teaching; research methods

3 Adapted physical education; physical education for handicapped persons

3 Motor learning

2 Children's physical education/elementary physical education

2 Education

2 Scientific principles of physical education (statistics \& measurement); appplied statistics

2 Social issues education; sociology of education

1 Administration

1 Health

1 Physical education supervision

1 Secondary education

1 Skill analysis

1 Student learning

*Total is more than 44 because many subjects used more than one descriptor when identifying the focus of their doctoral programs.

There are many reasons why so much difficulty exists in identifying teacher educators, as noted by Lanier and Little (1986). Metzler and Freedman (1985) commented on the lack of shared commonalities among PETE professors with involvement in teacher preparation. Data from the sample of PETE elders (who, coincidentally, are predominantly faculty members in higher education) in this study indicate that doctoral preparation is yet another area of diversity. Although it is interesting to note that the most common focus of doctoral study was related to teacher education, less than half of the elders in this academic village identified teacher education as a focus of their doctoral preparation. Although an attempt was made to group synonymous descriptors, difficulties in articulating what was studied by these subjects may be one more artifact of a missing shared technical culture (Lortie, 1975). Equally important, teacher preparation is not the sole mission of these individuals, nor is it the unique focus of the journal content. 
The value of the many different educational backgrounds of individuals who assume roles related to teacher preparation is unclear. It is possible that this range of backgrounds represents a strength. A gathering of many different perspectives to wrestle with the problems and issues surrounding teacher preparation may facilitate a healthy variety of approaches to the complexities of the field. It is also possible that this diversity represents a weakness. Without in-depth preparation, teachers and researchers may not have an adequate grounding in the needs, problems, and work already completed in the area. The result is likely to be a repetitive and/or disjointed approach to scholarship, without attention to the existing body of knowledge. The expansion of the knowledge base (in terms of useful knowledge) from such an approach is thus destined to continue at a slow rate, with many conceptual and factual holes.

At least one other interpretation of the varied educational backgrounds of leaders in this field, and there are many other possible interpretations, is that careers related to teaching in physical education are perceived to require little, if any, expertise. Hence, a specialized educational background is not required to teach and publish in the area. The leaders identified in this study may have been pressed into service by their institutions and have simply excelled. Clearly, important questions surrounding the career paths and role orientations of PETE professors continue to outnumber answers (cf. Mitchell \& Lawson, 1986).

\section{Gender}

Gender data have already been presented (see Tables 1 and 2) and will continue to be combined with various other descriptors. The data suggest a slight predominance of males in the subject pool. These findings are consistent with reports of characteristics of published authors in other fields. Creswell (1985) has suggested that although males are generally more published and cited than females, gender is an insignificant correlate of productivity when compared with other correlates.

In the present study, males account for more of the literature, as might be expected in the male-dominated world of higher education (where most of the authors are employed). It would appear that the historical evolution of departments of physical education through the combination of separate male and female departments into unified sections has not facilitated equality in terms of productivity in this particular journal. ${ }^{1}$ Although there is no explicit insight provided in these data as to why these differences exist, here may be another useful point of reference for future analyses of gender differences in the field of PETE.

\section{Prestige of Doctoral Program}

Ranking doctoral programs according to prestige is often criticized for a variety of shortcomings and oversights. Most studies attempting to represent and compare the prestige of programs have focused on attributes of the faculty rather than examining evidence of the effectiveness of the program (Hasbrook \& Loy, 1983). Furthermore, few studies take into account the multidisciplinary nature of these departments when attempting to rank them.

Hasbrook and Loy (1983) constructed a composite ranking of the top 22 programs in the United States. Their presentation was an attempt to combine several different ranking strategies into one. The authors noted a methodological weakness in their strategy - a possible overemphasis on similar program attributes (p. 139). Also warranting mention is the fact that this ranking appeared in 1983 and may not accurately reflect current levels of quality. Nonetheless, their ranking 
appears in Table 4 and provides a perspective on the leading departments granting doctoral degrees in physical education. In the present study, $65.9 \%$ of the subjects completed their doctoral work at one of these top schools, as indicated in Table 4. It would appear that the top schools account for the preparation of a strong majority of elders in the PETE discipline.

The Carnegie classification system (Carnegie Foundation, 1976) provides another type of ranking that may be interpreted to represent prestige. The Carnegie system is based on a blend of data, including federal financial support of academic science, number and types of degrees conferred, types of programs offered, and number of students enrolled. Subjects in this study completed their doctoral work at four Carnegie levels. Thirty-one subjects $(70.5 \%)$ graduated from schools in the Research University I category. This category was the level at which the majority of females $(64.7 \%)$ and males $(74.1 \%)$ studied. The Research University II category accounted for 8 subjects $(18.2 \%), 3$ subjects $(6.8 \%)$ completed their studies at the Doctoral Granting University I classification, and 2 subjects $(4.5 \%)$ graduated from institutions in the Doctoral Granting University II category. The distribution of types of schools by gender appears in Table 5.

\section{Table 4}

\section{Top Graduate Programs in Physical Education}

$\begin{array}{lcc}\text { 1. U. of Illinois } & 0 & 0 \\ \text { 2. U.C., Los Angeles } & 0 & 0 \\ \text { 3. Pennsylvania St. U } & 0 & 0 \\ \text { 4. U. of So. California } & 0 & 0 \\ \text { 5. Ohio St. U. } & 11 & 4 \\ \text { 6. U. of Wisconsin } & 2 & 0 \\ \text { 7. U.C., Berkeley } & 0 & 0 \\ \text { 8. U. of lowa } & 0 & 0 \\ \text { 9. U. of Massachusetts } & 3 & 4 \\ \text { 10. Florida St. U. } & 0 & 0 \\ \text { 11. U. of Michigan } & 2 & 0 \\ \text { 12. Indiana U. } & 1 & 0 \\ \text { 13. U. of Maryland } & 0 & 0 \\ \text { 14. Washington St. U. } & 0 & 0 \\ \text { 15. Springfield College } & 0 & 0 \\ \text { 16. U. of Oregon } & 2 & 1 \\ \text { 17. Columbia U. } & 1 & 1 \\ \text { 18. U. of Texas } & 1 & 1 \\ \text { 19. U.N.C., Greensboro } & 1 & 3 \\ \text { 20. Purdue U. } & 0 & 1 \\ \text { 21. Stanford U. } & 5 & 0 \\ \text { 22. Michigan St. U } & 0 & 0 \\ \text { Totals (\%) } & 29(65.9) & 15(34.1)\end{array}$

Note. Rankings based on Hasbrook and Loy (1983). 
Table 5

Institution Type by Gender

\begin{tabular}{|c|c|c|c|}
\hline Categories & Females (\%) & Males (\%) & Totals \\
\hline $\begin{array}{l}\text { Research University I } \\
\text { (\%) }\end{array}$ & $\begin{array}{l}11(35.5) \\
(64.7)\end{array}$ & $\begin{array}{l}20(64.5) \\
(74.1)\end{array}$ & $31(70.5)$ \\
\hline $\begin{array}{l}\text { Research University II } \\
(\%)\end{array}$ & $\begin{array}{l}3(37.5) \\
(17.6)\end{array}$ & $\begin{array}{l}5(62.5) \\
(18.5)\end{array}$ & $8(18.2)$ \\
\hline $\begin{array}{l}\text { Doctorate Granting University I } \\
(\%)\end{array}$ & $\begin{array}{l}3(100) \\
(17.6)\end{array}$ & $\begin{array}{l}0(0) \\
(0)\end{array}$ & $3(6.8)$ \\
\hline $\begin{array}{l}\text { Doctorate Granting University II } \\
(\%)\end{array}$ & $\begin{array}{l}0(0) \\
(0)\end{array}$ & $\begin{array}{l}2(100) \\
(7.4)\end{array}$ & $2(4.5)$ \\
\hline Totals & $17(38.6)$ & $27(61.4)$ & $44(100)$ \\
\hline
\end{tabular}

Note. Categories are from the Carnegie classification system (Carnegie Foundation, 1976).

These data are not unexpected. The majority of schools at which PETE elders (and aspiring elders) completed their doctoral work are major research universities. Faculty at such institutions are generally expected to demonstrate a commitment to research and publication. It is expected that graduates from these programs will share this commitment. The changing marketplace for graduates dictates that there are more people than jobs at the Research University I level; consequently, graduates must pursue jobs at lower institutions. The missions of many of these lower level institutions approximate those of the research universities, requiring the active involvement of faculty in research knowledge production and dissemination.

\section{Prestige of Current Employing Institution}

There is ample evidence in the literature to suggest that the prestige of the institution from which one receives the doctorate is a key factor in determining the prestige of the possible employing institutions. In particular, without a highprestige doctorate, there is little chance of a high-prestige job (Crane, 1970; Gross, 1970. 1971; Hurlburt, 1976; Long, 1978; Schichor, 1970). Massengale and Sage (1982) identified a similar pattern for graduate physical education faculty in what they described as a sponsored mobility versus a contest mobility system.

Rankings of employing institutions ${ }^{2}$ according to prestige in this study are presented using the two different ranking systems already introduced. In the present study, 5 subjects moved to careers outside of higher education or to institutions outside of the United States and were not evaluated in this section. Of the remaining 39 subjects, only $15(38.5 \%)$ were employed at institutions ranked in the top 22 by Hasbrook and Loy (1983). The locations and number of elders employed at these top institutions are illustrated in Table 4 . This number represents a drop from the 29 subjects (74.4\%) who received their degrees at these top institutions. 
The Carnegie Foundation's (1976) system of classification for institutions was also used to categorize employing institutions. The change from the level of the institution for education to the level of current employment is illustrated in Table 6. Of the 39 subjects, 24 (61.5\%) moved down in the system, $11(28.2 \%)$ moved to institutions at the same level, and 4 subjects $(10.3 \%)$ moved up. Distributions by gender with regard to moves are also illustrated in Table 6.

The trends noted with regard to career mobility in other disciplines and with graduate faculty in physical education are consistent with the evidence in this study. On a more dismal note, for those with upwardly mobile aspirations, the probability of assuming a position of lower prestige is greater than either staying at the same level or moving up. This outlook is more true for males than for females. The trends represented in these data also appear to reflect the extent to which institutions other than major research institutions are expecting their faculty to be active contributors to the knowledge base. The data suggest, furthermore, that lower level institutions recruit from institutions at which graduates are socialized to perform in such a fashion.

\section{Mentoring and Academic Genealogy}

Little (1990) provided a variety of definitions for the concept of mentoring, ranging from the classical interpretation to the more common expectations of mentors in educational settings - "teacher, sponsor, role model, confidant, and more"' (pp. 298-299). The extent to which mentors have actually been identified in the present study is uncertain. Subjects were asked to identify their major advisers, and these individuals may not have served in the full sense of the term mentor. As importantly, these advisers may not have served as subjects' sole mentors. It is hypothesized, however, that subjects' major advisers are important contributors to their education, reputation, and professional direction.

In an attempt to illustrate relationships among various PETE elders and their advisers, an academic genealogical chart was created (see Figure 1). The

Table 6

Prestige Change From Doctoral Study to Current Position by Gender

\begin{tabular}{rlll}
\hline Change & Females (\%) & Males (\%) & Totals \\
\hline Down & $7(29.2)$ & $17(70.8)$ & $24(61.5)$ \\
$(\%)$ & $(43.8)$ & $(73.9)$ & $4(10.3)$ \\
Up & $2(50)$ & $2(50)$ & $11(28.2)$ \\
$(\%)$ & $(12.5)$ & $(8.7)$ & \\
Same & $7(63.6)$ & $4(36.4)$ & 39 \\
$(\%)$ & $(43.8)$ & $(17.4)$ & $(100)$ \\
Totals & 16 & 23 & \\
$(\%)$ & $(100)$ & $(100)$ & \\
\hline
\end{tabular}

Note. Prestige rankings based on the Carnegie classification system (Carnegie Foundation, 1976). 

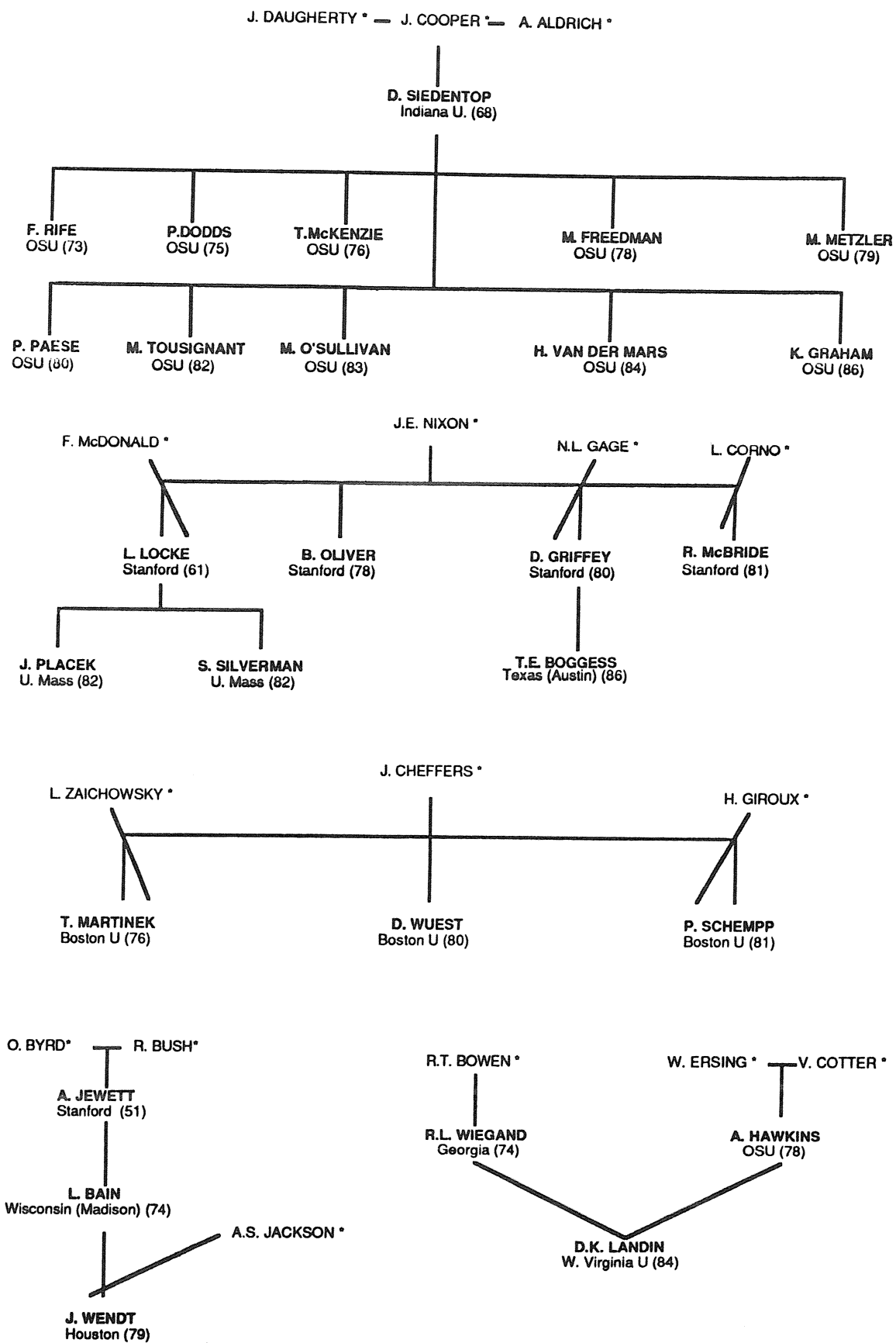

Figure 1 - Academic genealogy of major contributors to JTPE across the 1980s (Cont.). 


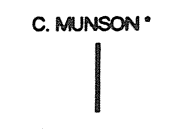

G. GRAMAM

U. of Oregon (73)

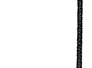

N. FAUCETTE Georgia (84)
H.H. CLARKE

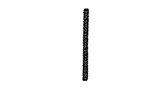

D.A. PHILLIPS

U. of Oregon (68)

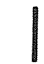

S. STROOT

U.N.C. Greley (87)

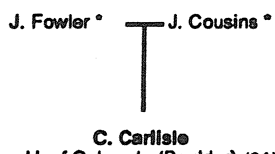

U. of Colorado (Boulder) (81)
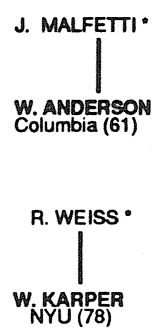

G. WEINSTEIN *<smiles>C=C</smiles>

P.GRIFFIN
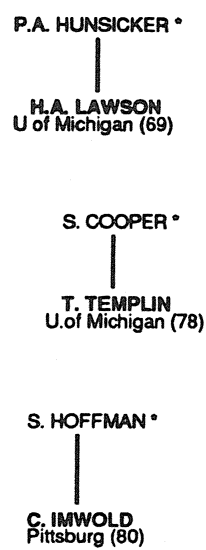
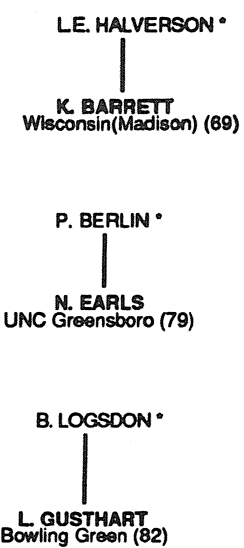
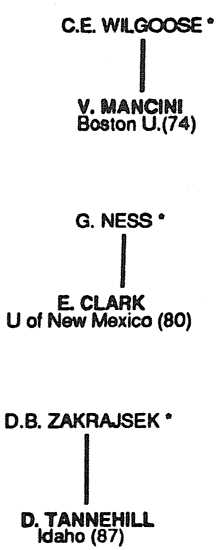

Figure 1 - Continued.

format of presentation follows the format first illustrated by Montoye and Washburn (1980). For each major contributor (author or coauthor of three or more articles), the major adviser(s), the institution at which the advanced degree was obtained, and the year of the degree are shown. Advisers shown with an asterisk did not contribute three or more articles to JTPE within the time period analyzed.

The chart should be interpreted as follows. Beginning with the first page of Figure 1, J. Daugherty, J. Cooper, and A. Aldrich were identified as advisers to D. Siedentop at Indiana University, where he graduated in 1968. Siedentop was identified as adviser to F. Rife, P. Dodds, T. McKenzie, M. Freedman, M. Metzler, P. Paese, M. Tousignant, M. O'Sullivan, H. van der Mars, and K. Graham at The Ohio State University. The next grouping on the chart identifies J. Nixon as the adviser to L. Locke (coadviser, F. McDonald), B. Oliver, D. Griffey (coadviser, N.L. Gage), and R. McBride (coadviser, L. Corno) at Stanford University. Remaining relationships should be interpreted similarly.

The paradigmatic communities identified by Lawson (1991) provide a basis for comparison with the current indicators of academic villages. Clearly, the Siedentop-sponsored interventionist research out of The Ohio State University is the most evident community. Eleven different authors can be traced back to this university, and 10 authors can be traced directly to Siedentop. The next most common institution is Stanford University, from which 5 authors hail; of these authors, 4 can be traced back to J. Nixon. The third most common institution is Boston University, at which 4 authors studied, 3 of them with J. Cheffers. 
The published work and the extent of influence of the authors identified in this genealogy is only one aspect of their scholarly efforts. Those familiar with the names on this chart can testify to the extensive influence of many of the scholars named. It would be an injustice to imply that the influence depicted in this chart represents the full extent of the contributions made by these individuals. Here lies a limitation of the present work when viewed as a historical chronicle.

\section{Conclusions and Implications}

The elders (or aspiring elders), along with links to other scholars and institutions, define one aspect of the professional development of PETE, at least in the United States. This information also provides a basis for future study of the activities of PETE professors and an accompanying expansion of the formal PETE knowledge base. Put differently, we now have some baseline information about key contributors to the knowledge base in a relatively young area of study. This information may serve as a point of comparison to professors in other areas of physical education and in other disciplines, both now and in the future. In particular, seven conclusions and accompanying implications may be drawn from the data presented in this study.

The first two conclusions are related. First, in the genealogical roots illustrated in Figure 1, there are several clearly dominant networks in evidence. In order of numerical prevalence, The Ohio State program, Stanford, and Boston University have been the sources of the largest networks of major contributors to JTPE across the first decade of existence. Second, of the 233 contributing authors to JTPE, only $44(18.9 \%)$ successfully published three or more articles in the journal. This finding is consistent with data on other university professors (Burch, 1989; Carnegie Foundation, 1985; Freeman, 1977) that suggest that the bulk of the published research in this country tends to be the result of the labor of a small number of people.

The first two conclusions suggest that only a select few contribute the majority of the work that is published, but why is this so? One interpretation is that only a small number of people choose these tasks for themselves. Another interpretation is that only a small number of people are talented enough to have their work published. More irreverent interpretations are offered by Sykes (1988). For example, the extent to which the review process in journals is truly "blind" has been questioned. The suggestion made is that select authors, because of who they are, have a stronger probability of having their work published. In short, questions abound with regard to who gets published, who does not get published, and why; and what gets published, what does not get published, and why. Sykes (1988) also raises the concern, however, that questions such as these may be moot in light of evidence that casts doubt over the following: (a) the espoused link between performing research and better teaching, (b) the merit of the majority of research, (c) the extent to which more than a handful of people ever read more than a fraction of what is written, and (d) the ability of anyone to keep up with what is already written. Put differently, who reads it or cares anyway? Answers to concerns such as these mark the boundaries of the future development of the knowledge base in PETE.

The third conclusion is related to the gender of the major contributors to $J T P E$. Across the decade studied, the majority (61.4\%) of these major contributors were male. This finding is consistent with previous work on publication behaviors of university professors (Creswell, 1985; Freeman, 1977). The increase in number of female authors in the present study, however, represents an interesting new 
trend. This finding may reflect success in terms of administration's attempts to provide more opportunities for females in the male-dominated world of higher education. Questions warranting attention involve the extent to which the gender balance is really changing in PETE and other areas. Furthermore, one wonders what the ramifications for PETE in the political arena of higher education might be as women approach parity in terms of numbers. Perspective on these issues may be gained from other works in which gender inequities in education have been explored (cf. Apple, 1983; Kelly \& Nihlen, 1982).

The fourth and fifth conclusions are related to the educational backgrounds of major contributors. All subjects hold doctorates, and most (65.9\%) received their degrees from high-prestige institutions (Hasbrook \& Loy, 1983). There are questions surrounding these conclusions. For example, do these trends reflect the socialization to value particular behaviors, namely, to research relevant issues and share findings with colleagues through publication? Or, do these data point to the notion of "thought police", discussed by Sykes (1988)? The latter interpretation is that specific types of questions and findings are more acceptable than others in spite of the "blind review" process (Sykes, 1988, pp. 122-128). The search for answers to these questions must involve insight into the editorial and review process to quantitatively determine what is submitted by whom compared to what is accepted and to qualitatively determine why some papers are accepted and others are rejected.

The sixth conclusion is tied to the focus of the subjects' doctoral study. Less than half of the subjects identified teacher education as a focus of their doctoral work. At least two lines of questions surface immediately. First, why did these individuals study what they studied? That is, was their selection of doctoral focus a thoughtful selection of alternatives to bring rich new insights into their work? Were other alternatives considered? Second, why did these authors choose to write about teaching (or related topics) in physical education? Did they study their first interest and simply not pursue it (i.e., motor learning)? Do they think of themselves as teacher educators? Clearly, there is much that is not known about teacher educators or about the major contributors to the knowledge base in PETE.

The final conclusion is that the majority $(65.9 \%)$ of major contributors, although initially from high-prestige institutions, currently work at lower prestige institutions (Hasbrook \& Loy, 1983). From a career-counseling standpoint, those who wish to work at a high-prestige institution should pursue a doctorate at a highprestige institution. It is possible to contribute to the knowledge base of the profession, however, regardless of the prestige of the employing institution. Indeed, it is often a requirement of professors at lower level institutions that are pursuing the prestige and following the model of higher prestige institutions. These data call into question the utility of institutional prestige with regard to evaluating major contributors to the knowledge base for the field of physical education. Furthermore, the problems with attempts to rank institutional prestige (cf. Hasbrook \& Loy, 1983) require caution in the interpretation of any related findings.

The data presented in this study are offered as a modest contribution to better understanding the leaders of the PETE academic village. The collection of individuals interested in and contributing to the study of teaching and teacher education in physical education is small, but growing. At the end of the first decade of existence of a refereed journal whose mandate is to disseminate information on the subject, it seems appropriate to also chronicle the individuals 
contributing this information. Future studies of more complex design and with loftier goals have another small foothold from which to proceed.

\section{References}

Apple, M.W. (1983). Work, gender and teaching. In A. Jewett, M. Carnes, \& M. Speakman (Eds.), Proceedings of the Third Conference on Curriculum Theory in Physical Education (pp. 3-37). Athens, GA: The University of Georgia, Division of HPERD.

Borrowman, M.L. (1965). Liberal education and the professional education of teachers. In M.L. Borrowman (Ed.), Teacher education in America: A documentary history (pp. 1-53). New York: Teachers College Press.

Burch, B.G. (1989). Perceptions of the role and scholarly reputation of the education professoriate. In R. Wisniewski \& E.R. Ducharme (Eds.), The professors of teaching: An inquiry (pp. 87-104). Albany, NY: State University of New York Press.

Carnegie Foundation for the Advancement of Teaching, The. (1976). A classification of institutions of higher education (rev. ed.). Berkeley, CA: Carnegie Council on Policy Studies in Higher Education.

Carnegie Foundation for the Advancement of Teaching, The. (1985). The faculty: Deeply troubled. Change, 17(4), 31-34.

Carter, H.L. (1981). Teacher educators: A descriptive study. Austin, TX: Research and Development Center for Teacher Education.

Clark, B.R. (1987). The academic life: Small worlds, different worlds. Princeton, NJ: Carnegie Foundation for the Advancement of Teaching and Princeton University Press.

Crane, D. (1970). The academic marketplace revisited: A study of faculty mobility using the Cartter ratings. American Journal of Sociology, 75, 953-964.

Creswell, J.W. (1985). Faculty research performance: Lessons from the sciences and the social sciences (ASHE-ERIC Higher Education Rep. No. 4). Washington, DC: Clearinghouse on Higher Education.

Dodds, P. (1989). Trainees, field experiences, and socialization into teaching. In T.J. Templin \& P.G. Schempp (Eds.), Socialization into physical education: Learning to teach (pp. 81-104). Indianapolis: Benchmark.

Freeman, B.C. (1977). Faculty women in the American university: Up the down staircase. In P.G. Altbach (Ed.), Comparative perspectives on the academic profession (pp. 160-190). New York: Praeger.

Gross, G.R. (1970). The organization set: A study of sociology departments. The American Sociologist, 5, 25-29.

Gross, G.R. (1971). Organizational prestige and academic career patterns. Dissertation Abstracts International, 32, 1641A.

Hasbrook, C.A., \& Loy, J.W. (1983). Publication and citation as measures of academic quality among graduate programs in physical education. Quest, 35, 131-144.

Hurlburt, B.M. (1976). Status and exchange in the profession of anthropology. American Anthropologist, 78, 272-284.

Judge, H. (1982). American graduate schools of education: A view from abroad (Report to the Ford Foundation). New York: Ford Foundation.

Kelly, G.P., \& Nihlen, A.S. (1982). Schooling and the reproduction of patriarchy: Unequal workloads, unequal rewards. In M.W. Apple (Ed.), Cultural and economic reproduction in education: Essays on class, ideology and the state (pp. 162-180). Boston: Routledge \& Kegan Paul.

Lanier, J., \& Little, J.W. (1986). Research on teacher education. In M.E. Wittrock (Ed.), Handbook of research on teaching (3rd ed., pp. 527-569). New York: Macmillan. 
Lawson, H.A. (1990). Constraints on the professional service of educational faculty. Journal of Teacher Education, 41(4), 57-70.

Lawson, H.A. (1991). Future research on physical education teacher education professors. Journal of Teaching in Physical Education, 10, 229-248.

Little, J.W. (1990). The mentor phenomenon and the social organization of teaching. Review of Research in Education, 16, 297-351.

Locke, L.F. (1984). Research on teaching teachers: Where are we now? Journal of Teaching in Physical Education, Monograph 2.

Long, J.S. (1978). Productivity and academic position in the scientific career. American Sociological Review, 43, 889-908.

Lortie, D.C. (1975). Schoolteacher: A sociological study. Chicago: The University of Chicago Press.

Massanari, K., Drummond, W.H., Houston, W.R., \& Edelfelt, R.A. (1978). Emerging professional roles for teacher educators. Washington, DC: American Association of Colleges for Teacher Education.

Massengale, J.D., \& Sage, G.H. (1982). Departmental prestige and career mobility patterns of college physical educators. Research Quarterly for Exercise and Sport, 53, 305-312.

Metzler, M.W., \& Freedman, M.S. (1981). Editor's pages. Journal of Teaching in Physical Education, Introductory Issue, 1-2.

Metzler, M.W., \& Freedman, M.S. (1985). Here's looking at you PETE: A profile of physical education teacher education faculty. Journal of Teaching in Physical Education, 4, 123-133.

Mitchell, M.F. (1988). Perceptions and preferences of physical education methods teacher educators in Ohio. Unpublished doctoral dissertation, The Ohio State University.

Mitchell, M.F. (1990a, January). Profile of PEMTEs: Present and future. Paper presented at the Commonwealth and International Conference on Physical Education, Sport, Health, Dance, Recreation and Leisure, Aukland, New Zealand.

Mitchell, M.F. (1990b, March). Professional implications of the scholarship behaviors of physical education methods teacher educators in Ohio. Paper presented at the national convention of the American Alliance of Health, Physical Education, Recreation and Dance, New Orleans.

Mitchell, M.F., \& Lawson, H.A. (1986). Career paths and role orientations of professors of teacher education in physical education. In M. Pieron \& G. Graham (Eds.), Sport pedagogy: The 1984 Olympic Scientific Congress proceedings (Vol. 6, pp. 41-46). Champaign, IL: Human Kinetics.

Montoye, H.J., \& Washburn, R. (1980). Research Quarterly contributors: An academic genealogy. Research Quarterly for Exercise and Sport, 51, 261-266.

Placek, J., \& Dodds, P. (1990, March). Teacher educators' perception of success and failure in their work. Paper presented at the American Alliance for Health, Physical Education, Recreation and Dance national convention, New Orleans.

Ryan, K.A. (1974). If I had it to do all over again... Theory into Practice, 13, 159-166. Safrit, M.J. (1979). Women in research in physical education. Quest, 31, 158-171.

Schempp, P., \& Graber, K. (1990, April). An ethnography of a teacher educator. Paper presented at the national convention of the American Educational Research Association, Boston.

Scott, M.W. (1990, March). Teacher education reform and institutional involvement. Paper presented at the national convention of the American Alliance for Health, Physical Education, Recreation and Dance, New Orleans.

Shichor, D. (1970). Prestige of sociology departments and the placing of new Ph.D.'s The American Sociologist, 5, 157-160. 
Sykes, C.J. (1988). ProfScam: Professors and the demise of higher education. New York: St. Martin's Press.

Williamson, K. (1990a). The ivory tower: Myth or reality? Journal of Teaching in Physical Education, 9, 95-105.

Williamson, K. (1990b, March). Physical education teacher educators' multiple work roles: Busy, not so happy and not so good. Paper presented at the national convention of the American Alliance for Health, Physical Education, Recreation and Dance, New Orleans.

Wisniewski, R., \& Ducharme, E.R. (Eds.) (1989). The professors of teaching: An inquiry. Albany, NY: State University of New York Press.

\section{Notes}

${ }^{1}$ The number of publications in JTPE does not necessarily represent the only refereed publications of the authors included in this study.

${ }^{2}$ The current employing institution refers to the institution of employment at the time of data collection-summer, 1990. Subjects may not be employed by the same institutions at the time of publication. Furthermore, the current institution of employment is not necessarily the first place of employment following receipt of the terminal degree. 